\title{
Issues and development trends of modern Icon painting
}

\author{
Marina Bobreshova* \\ Don State Technical University, 344022, Rostov-on-Don, Russia
}

\begin{abstract}
The article is concerned with topical issues and problem points of modern icon painting: understanding meanings and the mission of the icon in society, position of the Church, issue of the canon in icon painting, commercialization of the icon painter's work, etc. The main tasks of modern icon painting have been determined. For example, ability to find a harmony of artistic creation and icon painting canon; mastering the icon painting language and icon painting thinking; development of new iconography. Today, development trends of icon painting are seen in the return and preservation of the icon painting canon culture and in the interaction of the state and the Church in terms of the spiritual and professional education of modern icon painters. Today, an example of such an interaction is the joint icon painting department of the Rostov Art College named after M.B. Grekov and the Don Theological Seminary.
\end{abstract}

\section{Introduction}

Today, icon painting is on the path of a dynamic return, when interest in the icon painting culture as the national spiritual heritage has not weakened, the need to preserve and disseminate widely the Orthodox traditions is growing, and a steady trend has emerged in a highly spiritual and artistic approach to the professional performance of icon painting objects. Philosophers, art experts, culture experts, icon painters continue to study the ecclesiastical art and canonical icon in particular. The issues of the Orthodox art evolution and the theory of modern icon painting are raised by Archimandrite Zinon (Theodor), A.V. Andreeva, L.A. Armeeva, T.N. Artsybasheva, O.V. Gubareva, E.V. Drobnaya, S.S. Ostapenko, E.I. Ryadinskaya, A.S. Trapeznikova, Priest Nikolai Chernyshev, A.G. Zholondz, I.K. Yazykova and others. The practical icon painting experience of Archimandrite Zinon (Theodore), L.A. Armeeva, Hegumen Luka (Golovkov), Priest Nikolai Chernyshev, A.G. Zholondz and others is of interest. Particular attention is paid to the mission and understanding of the meanings of the icon, problem of the position of the Church, issue of the icon painting canon, tasks and prospects of the life of modern icon painting, development of modern iconography, which is reported in the conclusions of this research.

\section{Topical issues and problem points of modern icon painting}

\footnotetext{
${ }^{*}$ Corresponding author: rht-metodist@mail.ru
} 
Over the past two or three decades, a number of issues have matured and are being discussed in terms of modern icon painting. According to Archimandrite Zinon, the modern icon does not take its proper place in the divine service and has become an illustration for a celebrated event, which is reflected in its form - and this issue is one of the most important issues in modern icon painting. Today, "there is no established and expressed opinion of the Church about the ecclesiastical art, and far less there is control of the hierarchy over it" [1, p.3-4]. Bringing up the problem of the modern icon quality, Archimandrite Zinon writes that in order to penetrate the secrets of icon painting, the best examples are needed; the icon painting canon only disciplines the creator but mindlessly copying the pattern is pointless. The most dangerous thing in modern icon painting is a "substitution of tradition with selfexpression," since "as a rule, modern artists have shallow knowledge of Christianity" and "now many people, even art experts, have an incorrect perception of the icon" [1, p.8].

Priest Nikolai Chernyshev and A. Zholondz pay considerable attention to the canon as "the laws of the impact of God's grace on a human, and through him/her - on Christian culture, on humanity ..." [2, p.]. They give an assessment of the following issues: modernity of the icon, its dependence on the spirit of the age; need to study church traditions in full; icon appealing to new peoples and generations; issue of asceticism of the icon painter and his comprehensive adoption of the traditions of icon painting. Among the so-called dangers of today's icon painting, Priest N. Chernyshev and A. Zholondz indicate the oblivion of the traditions of asceticism, danger of creating an anti-icon, hidden theomachy; loss of the fullness and life-giving energy of the image in the practice of icon painting of the 20th century; dangerous strengthening of the non-Christian attitude to the image, which leads to portrayal of a set of conventions, worship of symbols, signs and illustrations [2].

O.V. Gubareva analyses the following problem situations and issues of modern icon painting: a problem of creating a school of contemporary Russian canonical ecclesiastical art; an issue of technical skill when a complex pictorial system of icon painting is closely connected with the theological concept of the work; situation of commercialization of the icon painter's work in the modern world, dependence on mass production, which becomes an integral part of the modern church culture; a problem of development of a new trend related to the Western European pictorial heritage, different from the canon and the mystical side of icon painting [3].

L.A. Armeeva, studying the correlation of the tradition and the author's principle in the system of education of a modern icon painter, calls the problem of "correlation of a single canon, conciliar experience of the Church with the individual creative work of the icon painter" extremely urgent [4]. Modern icon painting can also be reproached for copying implying by this concept secondariness. L.A. Armeeva believes that sometimes this comes from misunderstanding of the principles of the ecclesiastical art, which can be evaluated according to secular criteria. She calls it an extremely difficult task meaning the development of iconography of newly glorified new martyrs of the 20th century, which requires an "original creative approach" from the icon painter [4].

A.S. Trapeznikova also calls the creation of a new iconography as one of the main problems of modern icon painting and formulates the following causes of problems of an iconographic nature: the Church's uncertain position on the formation of a new iconography; difficulties in interpreting personal style and clothing of saints, especially those who died in the 20th century; portrait similarity in modern iconography; difficulty of forming multi-figure compositions; appearance of "false" icons" that respond to the chronicle of modernity and political events [5].

A.V. Andreeva, in her article "The Problems of the Canon and Innovation in Contemporary Church Painting", writes that understanding of the canon in the modern ecclesiastical art as a whole is rather ambiguous and calls "the danger that academic church painting brings to the church ..." as one of the problems of the modern ecclesiastical art [6]. 
She notes that significant attempts are being made today to revive the school of Orthodox icon painting, built on copying of canonical patterns. But one rarely finds a truly deep spiritual image among numerous copies of icons, and how justified is such a persistent emphasis on copying ancient icons [6].

In the process of analysing various aspects of studying and teaching icon painting at the turn of the 20th-21st centuries, S.S. Ostapenko indicated the following problems. First of all, different approaches to the study of the icon formed two fundamentally different views on the icon: a scientifically based, reasoned approach and "an aestheticized or psychologized perception of an image independent of spiritual experience and life and, above all, liturgical practice" [7]. The researcher draws our attention to the fact that "current consciousness has lost the sense of recognition of the icon" and she calls, first of all, "gospel texts, lives of the saints, church hymnography and the whole complex of patristic tradition" as the sources of correct understanding of the icon. She considers the issue of correct understanding of the meaning of the canon for "Christian life and work" to be a special topic for a modern audience [7].

I. Yazykova and Hegumen Luka Golovkov determine several problematic issues of modern icon painting. Firstly, this is underestimation of the ancient icon and passion for picturesque style, "some artists do not pay attention to the harmony between form and substance, iconography, language and theology, life of the icon painter and "mood of the image". Secondly, like A.L. Armeeva, they call copying, secondariness as a weak point of modern icon painting, although the copy list is an important component of icon painting [8]. Thirdly, painting icons "antique" deprives the image of the icon of truth and power. Fourth, many modern icon painters significantly roughen the features of the ancient icon in drawing, colour, technique, which entails the lack of a festive harmony inherent in the medieval icon. Fifth, the weakest thing today is the author's icon, new iconography, although the need for them is great. "The most difficult thing for an icon painter is to find harmony between adhering to a single canon and creativity", “... between following the tradition and innovation" [8].

E.I. Ryadinskaya subdivides the problems of the contemporary ecclesiastical art into two categories: external problems (organizational ones, with social connotation) and internal problems (specifics of icon painting). Today, there is an active search for the language of modern icon painting, and it is unknown where this search will lead. This raises a question of the need to search for identity of icon painting of the 20th and 21st centuries. A number of icon painters, including the school of Archimandrite Zinon, oppose raising the question of the search for the style and identity of icon painting of the 21 st century. According to E.I. Ryadinskaya, another important problem point is a mismatch between modern icon painting and architecture of the temple [9]. A variety of art trends, a range of tastes and opinions, many new temples and icons affect the level of not only icon painters, but also customers [9].

E.V. Drobnaya, discussing continuity as a determinative feature of culture and theoretical foundations of icon painting, says that the icon "expresses national spirituality as such, helps consolidate generations and revive the priority spiritual component of public consciousness" [10]. She concludes that today the task of society is to teach people to see the symbols of the icon, to understand its spiritual meanings, which will help answer questions of the meaning of life [10].

\section{Main tasks and development trends of modern icon painting}

In the process of discussing topical issues and problem points of modern icon painting, a natural question arises - what are the main tasks and development trends of icon painting of the 21 st century? Archimandrite Zinon considers that the Church's global task is "to raise 
people to the height of knowledge of God, and not to condescend to human ignorance", that is, "a person rejecting a truly Orthodox icon casts doubt on the correctness of his/her perception of worship and, in particular, the Eucharist, from which the icon is born "[1].

I. Yazykova and Hegumen Luka Golovkov consider that the main task of developing a new generation of icon painters is the ability to find "harmony of artistic creation and strict canon, human freedom and divine revelation, art and theology" in order to reach the heights of the "great tradition of the icon" [8].

In the book "Co-Creation of an Image. The Theology of Icon", I.K. Yazykova writes that new iconography has always been an evidence of vitality of the icon painting tradition, and she considers mastering of the icon painting language and icon painting thinking to be the primary task for modern icon painting [11].

According to T.A. Artsybasheva, the laws of creativity are poorly distinguishable in the newest Orthodox art and do not allow us to understand what happens - turning to the tradition or forming a new language? She analyses the work of the icon painting department of the Kursk Theological Seminary and says that this is almost the only attempt to restore the icon painting canonical tradition [12].

Today, there are other attempts to revive and preserve the icon painting canonical culture. For example, opening of the joint icon painting department of the Don Theological Seminary and the Rostov Art College named after M.B. Grekov in 2016. This is new experience of the network form of interaction between spiritual and secular educational institutions for education of icon painters. The content of education is based on the canonical principles of the icon painting school of the Moscow Theological Academy, which are implemented by copying the famous icon painting patterns [13]. The joint icon painting department contributes to the return of the canonical icon painting culture, which not only preserves the traditionally established icon painting objects by copying the patterns, but also educates an icon painter on the basis of the canonical model consisting of a religious spiritual foundation, expressive-figurative symbolic language and of the author's creative position, taking into account skills and knowledge of the academic school of drawing, painting and composition [13].

\section{Research methods}

In the process of writing the article, such research methods have been used as: systemic method, comparison, analysis, synthesis, generalization, induction and historical and iconographic research of modern icon painting. We have made the analysis by means of identifying theoretical points of view and practical experience; the listed opinions have been summarized and a conclusion has been formulated on the basis of individual facts. The dynamics of modern icon painting as a system has been studied and key points and trends of its development have been identified.

\section{Conclusion}

As a result of the analysis of topical issues, problem points and tasks of modern icon painting, the following points can be formulated. In modern society, there is no complete understanding of the meanings and mission of the icon; there is also no established position of the Church, which affects the content and form of the icon, the theoretical foundations and formation of the conceptual apparatus of modern icon painting.

The issue of the canon in modern icon painting is one of the most relevant issues and it is discussed in the following areas: the canon disciplines the icon painter and establishes the laws; interaction of the canon and individual creativity of the icon painter should contribute 
to the harmony between the canon and creativity; mechanical copying of the canonical icon leads to low-quality repetitions, to copying as secondariness; shallow knowledge of Christianity or a non-Christian attitude to the canonical icon leads to thoughtless conditional portrayal; problem of the influence of academic church painting, Western European art and the passion for picturesque style, which are fundamentally different from the icon painting canon.

Commercialization of the icon painter's work is a problem situation of icon painting, when the modern icon painter is dependent on the requirements of the market, the mass consumer, the level of the customer, which leads to appearance of "antique" icons, inconsistency of form and content, and style confusion of the modern icon.

The vital activity of modern icon painting is seen in the following. Firstly, in development of the modern icon through the search for the language of modern icon painting (taking into account the iconographic canonical traditions). Secondly, in formation of the modern school of Russian canonical ecclesiastical art; thirdly, in creation of a new iconography of both traditional plots and icons of the new martyrs. Fourth, in creation of new canonical patterns and a new icon script. Fifth, in striving for harmony between the objects of icon painting and the architecture of the temple.

Development of new iconography as a productive way of developing modern icon painting depends on the following points: opinion and position of the Church in relation to the ecclesiastical art; difficulties of interpreting personal and non-personal; penetration of portrait resemblance into the new icon; features of multi-figure composition of icons; mastering the icon painting language and icon painting thinking; emergence of a modern icon on a political topic, which contradicts the Orthodox spiritual traditions.

The mission of the icon occupies a special place in the problem field of modern icon painting. The conciliar essence of the icon is aimed at the process of rallying generations and strengthening the spiritual base of society. The spiritual meanings of the icon enable a person and society to answer questions of the meaning of life. A new icon painting language develops through the preservation and translation of the canonical traditions of the icon. This means that the great tradition of the icon strengthens the national spirituality and consciousness of modern society.

Thus, the main development trends of modern icon painting are seen in the further process of returning and preserving the icon painting canonical culture and in the interaction of the state and the Church in the spiritual and professional education of modern icon painters.

\section{References}

1. Zinon, Archimandrite, Conversations of the Icon Painter (Fund named after A. Men, Moscow, 1997)

2. Chernyshev, Priest, A. Zholondz, Issues of Modern Icon Veneration and Icon Painting, Alpha and Omega, 2(13), 259-279 (1997). Information on: http://www.artsobor.ru/archives/101

3. O. Gubareva, Problems of Modern Icon Painting. Svet Nevecherniy. Journal of the Vladimir Diocese, 4, 45-50 (2002)

4. L. Armeeva, Correlation of the Tradition and the Author's Principle When Copying Icons in the System of Education of a Modern Icon Painter, Bulletin of Kostroma State University named after N.A. Nekrasov. 4, 63-66 (2010)

5. A.Trapeznikova, To the Issue of Creating Icons of Newly-Glorified Saints at the Turn of the 20th-21st Centuries. Historical, Philosophical, Political and Legal Sciences, 
Cultural Studies and Art History, Issues of Theory and Practice, Gramota, 6 (32), 189191 (2013)

6. A. Andreeva, The Problems of the Canon and Innovation in Modern Church Painting, Bulletin of Moscow State Regional University, 3, 18-23 (2012)

7. S. Ostapenko, Studying and Teaching Icon Painting at the Turn of the 20th-21st Centuries: Philosophical, Ethical, Spiritual and Educational Aspects, Bulletin of Kostroma State University named after N.A. Nekrasov, 1, 50-54 (2011)

8. I. Yazykova, L. Golovkov Hegumen, Icon of the 20th Century. History of Icon Painting of the 6th-20th Centuries. Origins. Traditions. Modernity, Publishing House SIV, Moscow, 231-251 (2010)

9. E. Ryadinskaya, The Main Problems of Modern Ecclesiastical Art. Design Educationthe 21st Century, Materials of the Correspondence International Scientific-Practical Conference, 35-44 (2018)

10. E. Drobnaya, The Iconographic Canon and the Philosophical Justification of Its Representation in the Works of Contemporary Orthodox Artists, Humanitarian Vector, 2(38), 111-115 (2014)

11. I. Yazykova, Co-Creation of an Image. Theology of Icon (Publishing House BBE, Moscow, 2012)

12. T. Artsybasheva, From the History of Icon Painting in Russia of Modern and Contemporary Times: the 18th-20th Century, News of Russian State Pedagogical University named after A.I. Gertsen. Social and Humanitarian Sciences, 4(7), 220-224 (2004)

13. M. Bobreshova, Religious and Aesthetic Foundations of the Canonical Icon Painting Culture, Humanitarian and Socio-Economic Sciences, 5(102), 57-62 (2018) 